\title{
Aplikasi Peta Jalur Angkutan Umum Kota Manado Berbasis Mobile Web
}

\author{
Rigen Richo Gito Onsu, Yaulie D. Y. Rindengan, Feisy D. Kambey \\ Teknik Informatika Universitas Sam Ratulangi Manado, Indonesia. \\ rigen.onsu@gmail.com, rindengan@gmail.com, feisykambey@unsrat.ac.id
}

\begin{abstract}
Abstrak - Perkembangan teknologi informasi telah berkembang pesat dalam membantu masalah Sistem Informasi Geografis (SIG) terutama dalam bidang transportasi. Penelitian ini adalah untuk mengimplementasikan informasi peta jalur angkutan umum Kota Manado ke dalam bentuk aplikasi berbasis Mobile Web, dengan menggunakan Google Maps sebagai tampilan informasi peta jalur angkutan umum Kota Manado. Pengembangan aplikasi peta jalur angkutan umum Kota Manado ini menggunakan metode Rapid Application Development (RAD). Aplikasi peta jalur angkutan umum Kota Manado ini membantu pengguna dalam mendapatkan informasi jalur angkutan umum yang ada di Kota Manado, baik wisatawan asing maupun lokal beserta warga Kota Manado yang belum mengetahui jalur angkutan umum Kota Manado.
\end{abstract}

Kata Kunci : SIG, Google Maps, RAD, Angkutan Umum, Manado.

\section{PENDAHULUAN}

Berkembangnya ilmu pengetahuan dan teknologi pada saat ini sangat berpengaruh pada masyarakat Indonesia, terutama pada Sistem Informasi Geografis (SIG) yang banyak memperoleh perhatian masyarakat, karena dengan SIG kita dapat mengetahui banyak hal yang ada di permukaan bumi ini, salah satunya di bidang Transportasi Umum di Kota Manado.

Seiring dengan perkembangan jaman, kebutuhan akan informasi menjadi hal yang dibutuhkan. Informasi yang cepat dan tepat juga sangat diperlukan. Hal ini menjadikan penyampaian Informasi yang berbasis Mobile Web sebagai pilihan.

Kota Manado yang selama ini dikenal sebagai tujuan dari berbagai kalangan Masyarakat Lokal maupun Asing tentunya membutuhkan Sarana Transportasi yang memadai selain kendaraan pribadi. Salah satu sarana Transportasi penting yang menunjang keberhasilan aktivitas Masyarakat di kota Manado adalah angkutan umum. Pengguna angkutan umum bervariasi dimulai dari Pelajar, Mahasiswa, Karyawan, Warga Sipil, bahkan wisatawan Lokal maupun Mancanegara. Wisatawan Lokal maupun Mancanegara memerlukan sebuah sarana Transportasi dalam perjalanan mereka di kota Manado.

Pengguna jalur angkutan umum di Kota Manado masih banyak kesulitan dalam menentukan dimana jalur-jalur yang akan dilewati oleh angkutan umum. Hal ini disebabkan tidak adanya Informasi yang jelas tentang jalan-jalan yang dilalui jalur angkutan umum. Hal ini dapat terjadi mengingat pengguna angkutan umum bervariasasi, seperti pengguna angkutan yang wisatawan Asing, Wisatawan Lokal ataupun Mahasiswa baru yang tidak mengetahui jalan-jalan di Kota Manado.

Dilatarbelakangi oleh masalah di atas, maka perlu dibuat suatu perangkat lunak tentang Aplikasi Peta Jalur Angkutan Umum. Perangkat Lunak ini diharapkan dapat memberikan informasi yang dibutuhkan oleh pengguna angkutan umum yang ada di Kota Manado. Dengan latar belakang yang ada maka Perangkat Lunak yang dibangun berjudul "Aplikasi Peta Jalur Angkutan Umum Kota Manado Berbasis Mobile Web".

\section{DASAR TEORI}

\section{A. Sistem Informasi Geografis (SIG)}

Sistem Informasi Geografis (Geographic Information System GIS) adalah sistem informasi khusus yang mengelola data yang memiliki informasi spasial (bereferensi keruangan). Atau dalam arti yang lebih sempit, adalah sistem komputer yang memiliki kemampuan untuk membangun, menyimpan, mengelola dan menampilkan informasi berefrensi geografis, misalnya data yang diidentifikasi menurut lokasinya, dalam sebuah database. Para praktisi juga memasukkan orang yang membangun dan mengoperasikannya dan data sebagai bagian dari sistem ini. Teknologi Sistem Informasi Geografis dapat digunakan untuk investigasi ilmiah, pengelolaan sumber daya, perencanaan pembangunan, kartografi dan perencanaan rute. Misalnya, SIG bisa membantu perencana untuk secara cepat menghitung waktu tanggap darurat saat terjadi bencana alam, atau SIG dapat digunaan untuk mencari lahan basah (wetlands) yang membutuhkan perlindungan dari polusi.

Menurut Aronoff (1989), Sistem Informasi Geografis (SIG) adalah seperangkat kerja baik secara manual maupun didukung oleh piranti komputer yang dapat melakukan koleksi, menyimpan, mengelola, serta menyajikan data dan informasi yang bergeoreferensi untuk tujuan tertentu. Dari sini tampak bahwa data yang diolah dalam metode Sistem Informasi Geografis atau disingkat SIG haruslah mengacu pada sistem koordinat tertentu.

\section{B. Aplikasi}

Aplikasi adalah suatu unit perangkat lunak yang dibuat untuk melayani kebutuhan akan beberapa aktifitas seperti sistem perniagaan, pelayanan, masyarakat, periklanan, atau semua proses yang dilakukan manusia. (Hengky W.Pranama, 2006) 
Menurut Kadir, (2003, h.204) aplikasi adalah suatu program yang dibuat oleh pemakai yang ditujukan untuk melakukan suatu tugas khusus.

Berdasarkan dua definisi aplikasi maka dapat disimpulkan bahwa aplikasi adalah suatu program atau perangkat lunak yang dibuat untuk melakukan tugas khusus untuk melayani kebutuhan kebutuhan manusia dalam berbagi aktivitas seperti perniagaan, pelayanan masyarakat, dan perikanan.

\section{Web}

Secara teknis, web adalah sebuah sistem dimana informasi dalam bentuk teks, gambar, suara, dan lainnya yang tersimpan dalam sebuah Internet Webserver ditampilkan dalam bentuk hypertext. Informasi dalam bentuk teks di web ditulis dalam format HTML. (Sutanta,2005)

Secara umum, untuk menjelajahi internet (browsing surfing), harus diketahui alamat yang dituju. Aturan penulisan alamat tersebut adalah protocol (http://domain(www.akprind.ac.id). (sutanta, 2005)

\section{Mobile Web}

Mobile web adalah system yang bertujuan untuk mengakses layanan data secara wireless dengan menggunakan perangkat mobile seperti handphone, PDA yang tersambung ke sebuah jaringan telekomunikasi selular. Mobile web yang diakses melalui perangkat mobile perlu dirancang dengan mempertimbangkan keterbatasan perangkat mobile seperti sebuah handphone yang memiliki layar dengan ukuran yang terbatas ataupun beberapa keterbatasan pada sebuah perangkat mobile.

Pada Mei 2003 mobile web dikeluarkan oleh W3C dengan nama Mobile Web Initiative (MWI) dengan tujuan membuat web dapat diakses dari sebuah perangkat mobile secara sederhana seperti mengakses web dari sebuah komputer desktop. Pada mobile web juga dikenal dengan sebutan mobile web 2.0, yang dapat diartikan membawa teknologi web 2.0 ke sebuah mobile device. Tetapi perangkat mobile berbeda dengan komputer desktop, sehingga banyak faktor yang menjadi batasan ketika membangun sebuah mobile web. Salah satunya adalah ketersediaan data secara real time atau update berkala ketika terjadi perubahan data pada web. (Obie, 2008)

\section{E. Google Maps Api}

Google Maps API adalah suatu library yang berbentuk JavaScript. Cara membuat Google Maps untuk ditampilkan pada suatu web atau blog sangat mudah hanya dengan membutuhkan pengetahuan mengenai HTML serta JavaScript, serta koneksi Internet yang sangat stabil. Dengan menggunakan Google Maps API, kita dapat menghemat waktu dan biaya untuk membangun aplikasi peta digital yang handal, sehingga kita dapat fokus hanya pada data-data yang akan ditampilkan. Dengan kata lain, kita hanya membuat suatu data sedangkan peta yang akan ditampilkan adalah milik Google sehingga kita tidak dipusingkan dengan membuat peta suatu lokasi, bahkan dunia.

\section{F. Rapid Application Development (RAD)}

Rapid Application Development adalah suatu pendekatan berorientasi objek terhadap pengembangan sistem yang mencakup suatu metode pengembangan serta perangkatperangkat lunak (Kendall: 2003).

Dalam tahapan Rapid Application Development (RAD) terdapat tiga fase yaitu:

a. Requirements planning (Perencanaan Persyaratan), yaitu:

Pada fase ini, pengguna dan penganalisis bertemu untuk mengidentifikasikan tujuan-tujuan sistem atau sistem serta untuk mengidentifikasikan syarat-syarat informasi yang ditimbulkan dari tujuan-tujuan tersebut. Orientasi dalam fase ini adalah menyelesaikan masalah-masalah perusahaan. Meskipun teknologi informasi dan sistem bisa mengarahkan sebagian dari sistem yang diajukan, fokusnya akan selalu tetap pada upaya pencapaian tujuan-tujuan perusahaan.

b. RAD design workshop, yaitu:

Mengidentifikasi solusi alternatif dan memilih solusi yang terbaik. Kemudian membuat desain proses bisnis dan desain pemrograman untuk data-data yang telah didapatkan dan dimodelkan dalam arsitektur sistem informasi. Tools yang digunakan dalam pemodelan sistem biasanya menggunakan Unified Modeling Language (UML).

c. Implementation (Penerapan), yaitu:

Setelah Design Workshop dilakukan, selanjutnya sistem di-implementasikan (coding) ke dalam bentuk yang dimengerti oleh mesin yang diwujudkan dalam bentuk program atau unit program. Tahap implementasi sistem merupakan tahap meletakkan sistem supaya siap untuk dioperasikan.

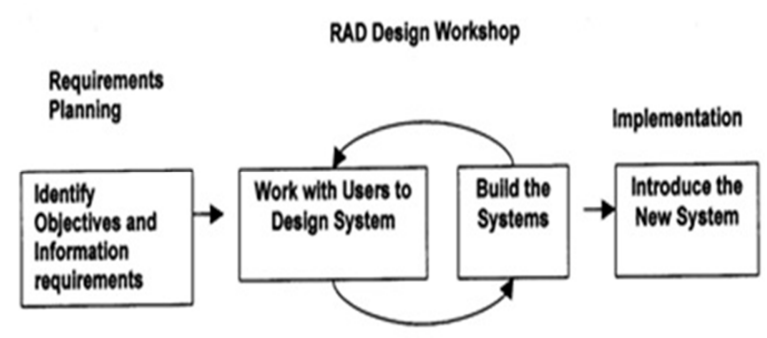

Gambar 2.4 Tahapan RAD (Kendall, 2008) 


\section{Metodologi Penelitian}

\section{A. Metode Pengumpulan Data}

Metode penelitian yang diterapkan dalam mendapatkan data dan informasi yang mendukung dalam penelitian ini adalah sebagai berikut:

1. Studi Pustaka

Penelitian kepustakaan digunakan sebagai bahan dasar pembahasan secara teoritis dengan menggunakan data yang diperoleh dari lapangan dan mengevaluasi hasil penelitian, teori-teori dan pandangan dari buku-buku, bahan kuliah, pencarian melalui internet dan sumber-sumber lainnya dalam penulisan karya tulis ini.

2. Studi Lapangan

Dalam melakukan penelitian di lapangan akan didapatkan data yang terdapat dalam dokumendokumen instansi terkait, serta langsung mengamati, mengevaluasi, sistem informasi jalur-jalur angkutan umum Kota Manado. Pada penelitian ini juga akan dilakukan wawancara dengan narasumber atau pihakpihak yang berhubungan dengan masalah-masalah tersebut.

a. Teknik wawancara, yaitu dengan langsung bertatap muka dengan pihak-pihak terkait yaitu Dinas Perhubungan dan sopir angkutan umum.

b. Teknik observasi, yakni dengan melakukan pengamatan langsung terhadap hal-hal yang berhubungan dengan sistem informasi jalur angkutan umum tersebut. Observasi dilakukan pada rute jalur angkutan umum dikota manado.

\section{B. Metode Penelitian}

Prosedur penelitian merupakan kerangka kerja yang digunakan dalam melaksanakan penelitian. Berikut adalah kerangka kerja yang dalam membangun aplikasi ini:

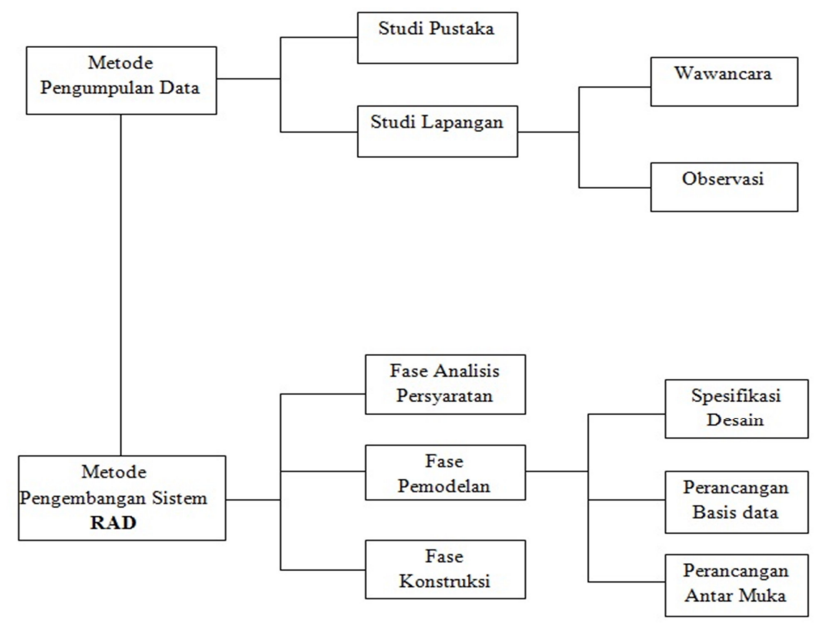

Gambar 3.1 Kerangka Berpikir Penelitian

\section{Spesifikasi Desain}

Use Case Diagram dirancang untuk menunjukkan secara umum fungsi dan tanggung jawab masing-masing aktor dalam Sistem Jalur Angkutan Umum yang akan dirancang.

\section{Use Case Diagram}

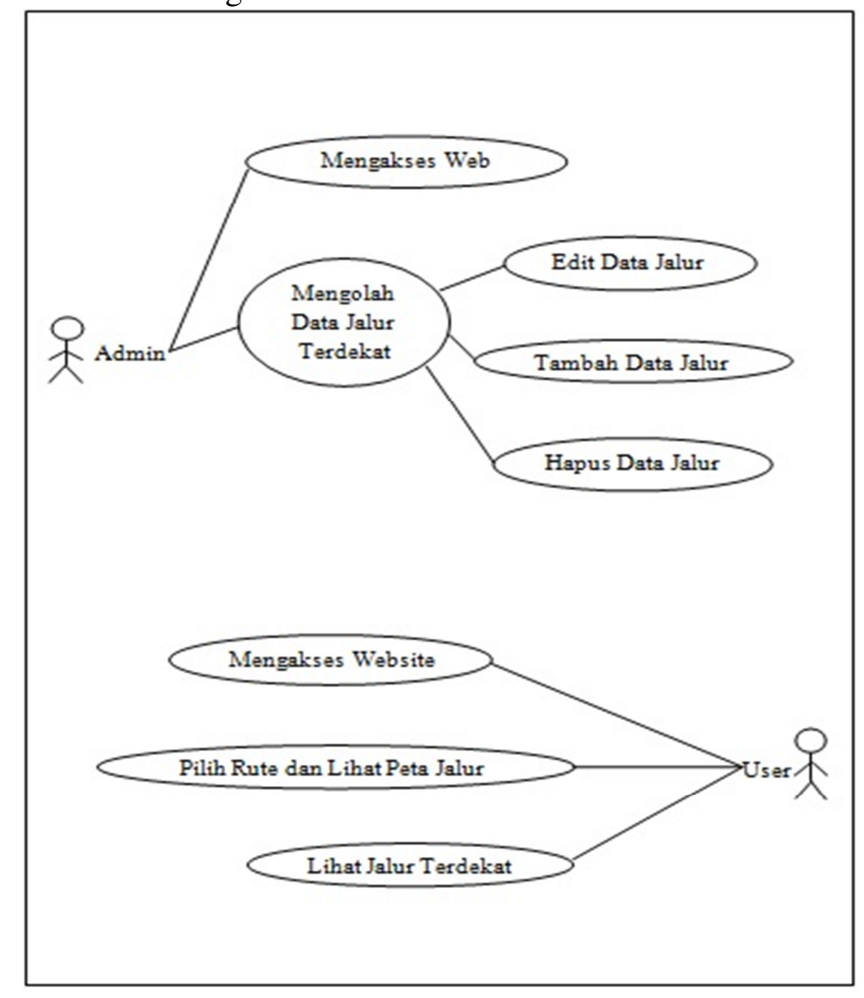

Gambar 3.2 Use Case Diagram Aplikasi Peta Jalur angkutan Umum

Gambar 3.2 menjelaskan tentang Use Case Diagram dirancang untuk menunjukkan secara umum fungsi dan tanggung jawab masing-masing aktor dalam Sistem Jalur Angkutan Umum. 
2. Activity Diagram

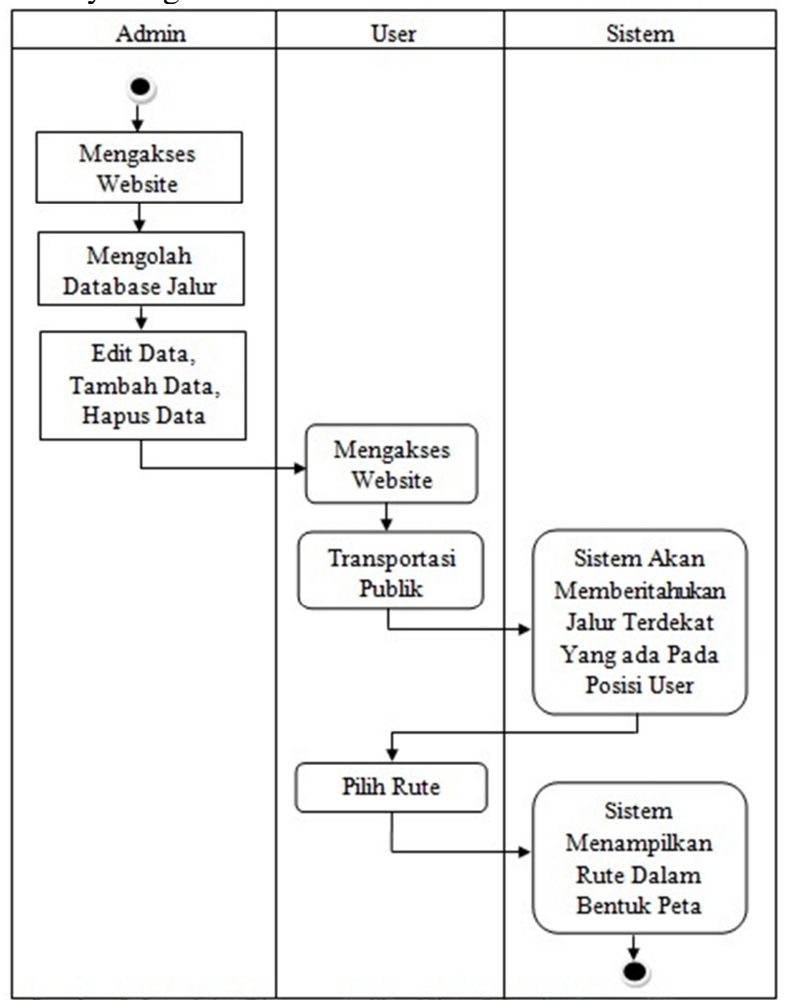

Gambar 3.3 Activity Diagram Aplikasi Peta Jalur Angkutan Umum

Pada gambar 3.3 Activity diagram menjelaskan tentang proses yang terjadi didalam aplikasi yang akan dirancang dan dibuat yang berkaitan dengan admin dan pengguna yang ada. Proses yang terjadi pada gambar diatas dapat dijelaskan sebagai berikut:

1. Admin mengakses website untuk mengola database dari aplikasi peta jalur angkutan umum.

2. Admin melihat data jalur, mengedit data jalur, menambah data jalur dan menghapus jalur.

3. Sebelum masuk ke aplikasi pastikan user terhubung dengan koneksi internet.

4. Kemudian user mengakses website.

5. User pilih kolom rute kemudian user akan memilih rute dengan cara mencentang rute yang telah disediakan lalu sistem akan menampilkan jalur yang dipilih ke dalam bentuk peta.

6. User pilih kolom transportasi publik disini sistem akan memberitahukan jalur terdekat yang ada pada posisi dari user sehingga user dapat mengetahui jalur apa saja yang ada disekitar posisi user.

\section{IV . Hasil dan Pembahasan}

Setelah membuat perancangan aplikasi juga telah mengikuti tahapan-tahapan metodologi yang ada, yaitu metodologi RAD dalam proses pembuatan aplikasi yakni aplikasi peta jalur angkutan umum kota manado berbasis mobile web, maka pada bagian ini akan dibahas bagaimana aplikasi ini berjalan juga membahas fungsi yang ada didalamnya.

\section{A. Tampilan Transportasi Publik}

Pada tampilan awal aplikasi peta jalur angkutan umum Kota Manado berbasis mobile web dapat dilihat pada gambar 4.1.
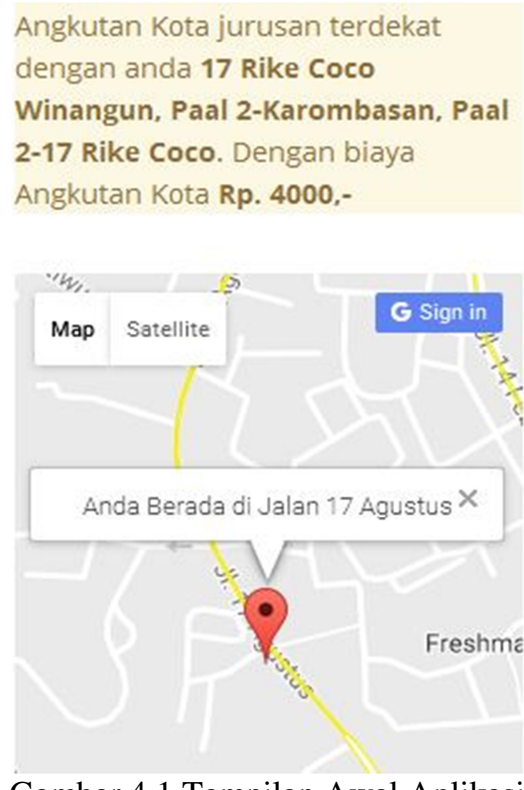

Gambar 4.1 merupakan tampilan awal aplikasi peta jalur angkutan umum kota manado berbasis mobile web, pada tampilan awal aplikasi ini user langsung diarahkan ke menu transportasi publik disini user dapat mengetahui posisi user berada dijalan 17 agustus dan user dapat mengetahui jalur terdekat dijalan 17 agustus yaitu 17 rike coco winangun, paal 2,17 rike coco dengan biaya Rp.4000/org.

B. Tampilan Rute

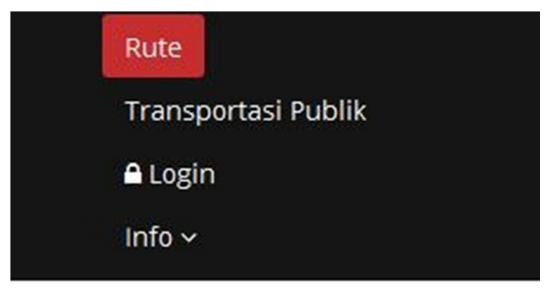

Halaman Rute merupakan halaman informasi yang memuat rute transportasi publik yang berada di Kota Manado, setiap rute diwarnai berdasarkan Basis rutenya.

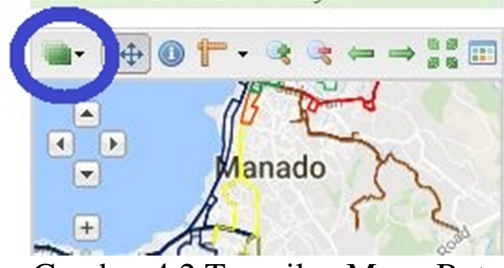

Gambar 4.2 Tampilan Menu Rute 
Gambar 4.2 merupakan tampilan menu rute. Pada menu ini penumpang akan memilih rute jalur angkutan umum Kota Manado yang telah disediakan dan rute dapat dilihat dalam tampilan peta.

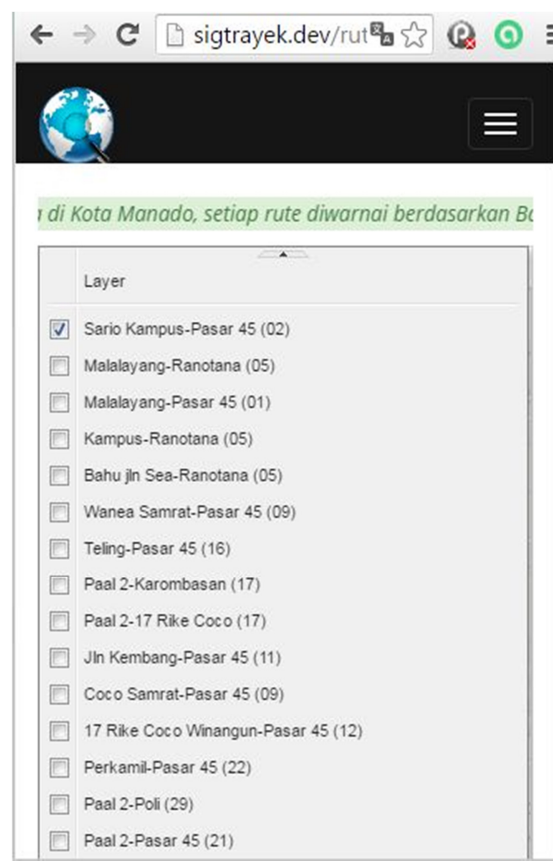

Gambar 4.3 Tampilan Pilih Jalur Sario Kampus-Pasar 45

Gambar 4.3 merupakan tampilan dari jalur yang akan dipilih dengan mencentang jalur tersebut yaitu sario kampus-pasar 45.
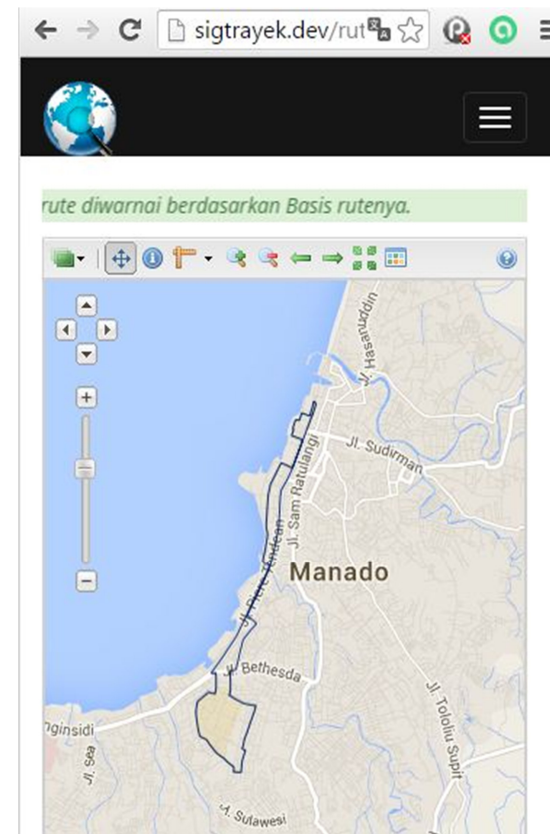

Gambar 4.4 Tampilan Peta Jalur Sario Kampus-Pasar 45

Gambar 4.4 merupakan tampilan setelah penumpang memilih jalur sario kampus-pasar 45. Untuk melihat tampilan peta jalur agar lebih dekat bisa diperbesar-diperkecil.

\section{IV.PENUTUP}

\section{A. Kesimpulan}

Dari hasil penelitian ini, telah dihasilkan suatu Sistem Informasi Geografis Jalur Angkutan Umum di Kota Manado berbasis mobile web yang dapat digunakan sebagai sarana transportasi untuk mempermudah perjalanan pengguna angkutan yang ada di Kota Manado.

Dengan aplikasi ini dapat lebih mudah masyarakat untuk memilih jalur-jalur trayek yang ada di Kota Manado.

B. Saran

Penulis menyadari bahwa Sistem Informasi Geografis yang dibuat masih banyak kekurangan dan penulis mengharapkan agar kedepannya nanti Sistem Informasi Geografis yang akan dibuat bisa lebih dikembangkan lagi dengan menambahkan estimasi waktu perjalanan yang ditempuh.

\section{DAFTAR PUSTAKA}

[1] Geographic Information Systems: A Management Perspective. WDLPublications, Otawa, Canada, 294295. Aronoff, S.1989.

[2] Aplikasi Inventory Berbasis Access 2003, Elex Media Komputindo, Jakarta. Hengky W. Pramana, (2006).

[3] Gordon B. Davis, Kerangka Dasar Sistem Informasi Manajemen Bagian 1, PT Pustaka Binamas Pressindo, Pengenalan Sistem Informasi, Andi, Yogyakarta. Jakarta: 1991.Kadir, A., (2003).

[4] Pengantar Teknologi Informasi. Yogyakarta: Graha Ilmu. Sutanta, Edhy. 2005.

[5] Perbandingan Kinerja Berbagai Algoritma Kompresi Pada Berbagai Tipe File. Bandung: Teknik Informatika ITB. Hadrian, Obie. (2008).

[6] Analisis \& Perancangan aplikasi. Jakarta : Index. Kendall.2008.

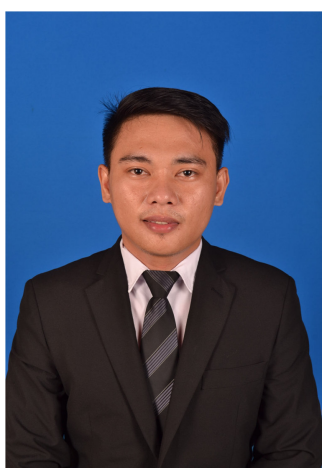

Sekilas dari penulis dengan nama lengkap Rigen Richo Gito Onsu, lahir di Ranolambot, Minahasa, Provinsi Sulawesi Utara, anak ke 1 dari 2 bersaudara. Dengan Pendidikan Sekolah Dasar Negeri 70 Manado. Kemudian melanjutkan ke Sekolah Menengah Pertama Katolik. St. Rafael Manado. Kemudian melanjutkan ke Sekolah Menengah Kejuruan (SMK) Negeri 2 Manado. Setelah lulus tahun 2010 melanjutkan ke Perguruan Tinggi di Universitas Sam Ratulangi Manado dengan mengambil Jurusan Teknik Informatika. Pada tanggal 29 September 2016 Penulis Resmi lulus di Teknik Informatika Universitas Sam Ratulangi Manado dan menyandang gelar Sarjana Komputer. 